\title{
Web-Based Information and Entertainment Portal Development Using Igniter Code Framework
}

\author{
Diondy Kusuma ${ }^{a}$, Sonya Rapinta Manalu \\ ${ }^{\mathrm{a}, \mathrm{b}}$ Computer Science Department, School of Computer Science, Bina Nusantara University, Jakarta, Indonesia 11480 \\ b sonyamanalu@binus.ac.id
}

Article History: Received: 10 November 2020; Revised 12 January 2021 Accepted: 27 January 2021; Published online: 5 April 2021

\begin{abstract}
The purpose of making this web-based information and entertainment portal application is to develop a portal that can be used by the public in obtaining entertainment and information about trends and lifestyle. In addition, this application is also made with the aim of developing information and entertainment portals that can facilitate content contributors so that they can share ideas and participate in the production of content available on this portal. The method used to develop this web-based information and entertainment portal application is the waterfall method using the Code Igniter framework. Evaluation of this application is carried out with two approaches namely questionnaire and comparison with similar applications. The end result of the development of this application is a web-based portal called Cacta Media that provides information and entertainment in the form of articles and videos.
\end{abstract}

Keywords: Cacta media, code igniter framework, information and entertainment portal application.

\section{Introduction}

Information and entertainment has now become a basic need of the community. The community's need for information and entertainment is used by various mass media in conveying information and entertainment to its readers. Where the dissemination of information and entertainment can be done through newspapers, television, radio and online media. As time goes by and as technology develops, people find it easier to obtain information and entertainment quickly through the internet.

The use of the internet to access information and entertainment is increasing. This is because the media accessed online has several advantages over conventional media, which is very fast in presenting information and entertainment, can be accessed from anywhere and at any time. These advantages make people increasingly prefer to access information through online media.

The following is also the result of a survey regarding internet usage in Indonesia

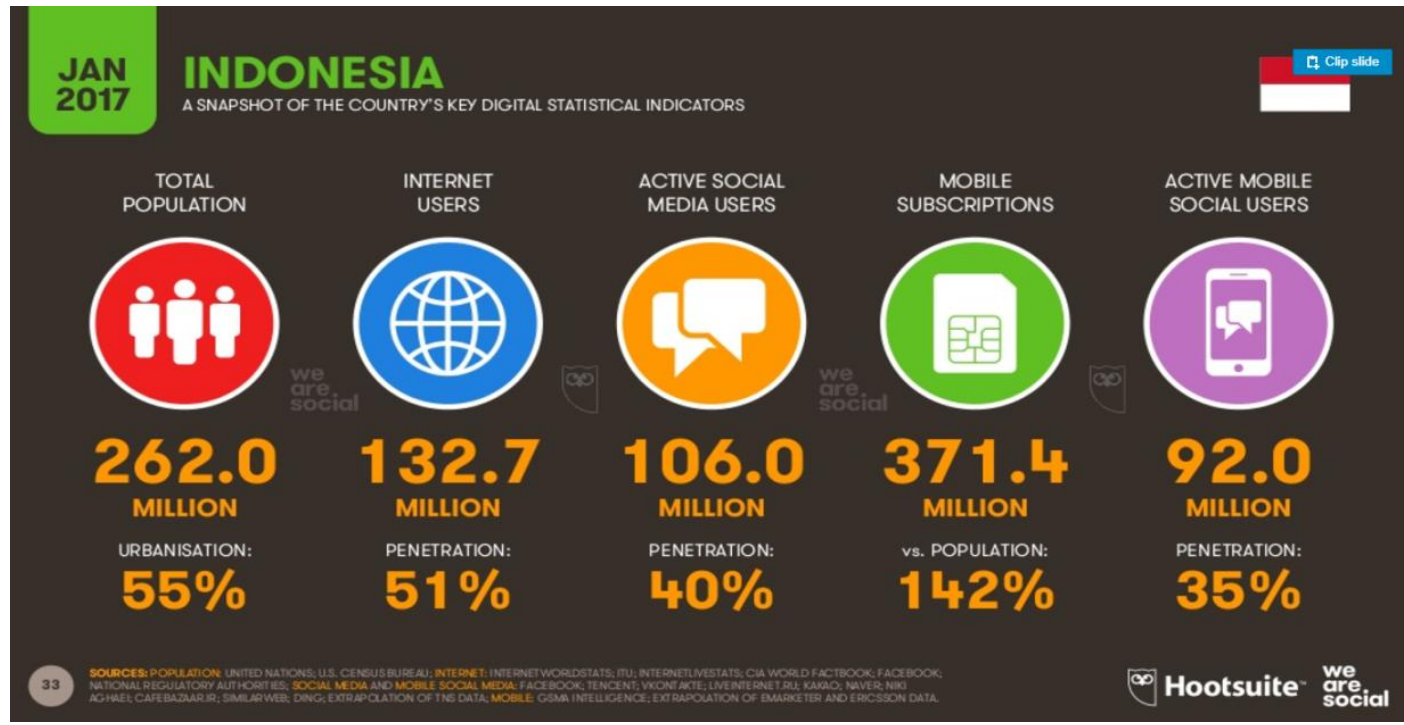

Fig. 1. Statistics of Internet Users in Indonesia

(Source: https://www.slideshare.net/wearesocialsg/digital-in-2017-southeast-asia ) [1] 
From the survey results it can also be seen that a very large population in Indonesia and developing internet users can be a potential for online media development. The following are also the results of a survey regarding the time spent by Indonesians in accessing information and entertainment:

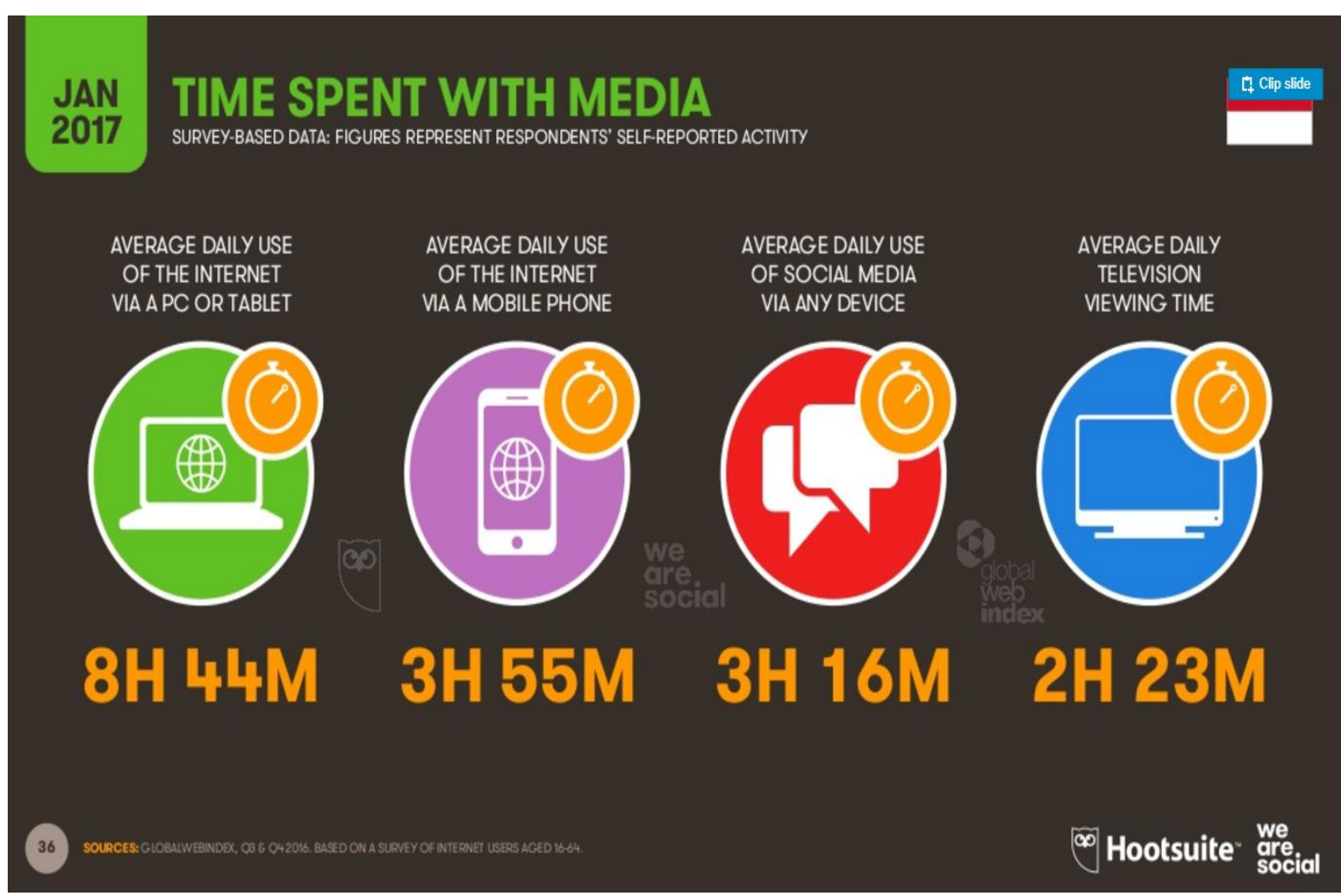

Fig. 2. Statistics of Time Spent by Media Users in Indonesia

(Source: https://www.slideshare.net/wearesocialsg/digital-in-2017-southeast-asia ) [1]

The following is the formulation of the problem obtained based on the background described above:

1. How to develop a web-based portal that can be used by the public to meet their needs for information and entertainment?

2. How to develop a web-based portal that is able to facilitate content contributors in sharing information and entertainment?

3. How to develop and implement Facebook pixel on a web-based portal?

The objectives of the research and development of this web-based information and entertainment portal are:

1. Develop a portal that can be used by the public in obtaining entertainment and information about trends and lifestyle

2. Develop information and entertainment portals that can facilitate content contributors

The benefits of research and development of this web-based information and entertainment portal are:

1. Provide quality information and entertainment for the community

2. Make it easy for others to be able to express their opinions and ideas and become contributors of content through this web-based.

\section{Research Methods}

\section{Literature Study Methods}

Literature study method is done by looking at and reading journals and books about the development of the system to be developed.

2. Questionnaire Method 
The questionnaire was created to find out what is expected by young people with a vulnerable age of 15-35 years with this online media designed.

Based on the results of the questionnaire, it will determine what features should be developed and what kind of content the prospective user wants. The questionnaire was distributed online to respondents.

\section{Observation Method}

Observations are made by observing the processes that occur in online media that spread among young people. Observation is very helpful in designing the system to be made.

\section{Design Method}

The design method used is Waterfall Development according to Ian Sommerville which includes:

1) Requirements Definition

2) System and Software Design

3) Implementation and Unit Testing

4) Integration and System Testing

5) Operation and Maintenance

\section{System Planning}

From the results of data collection, an UML was designed to do the basic design of the Cacta Media application. Here is a picture of the Use Case Diagram to illustrate the features that exist in the Cacta Media System and the interaction between actors and the system.

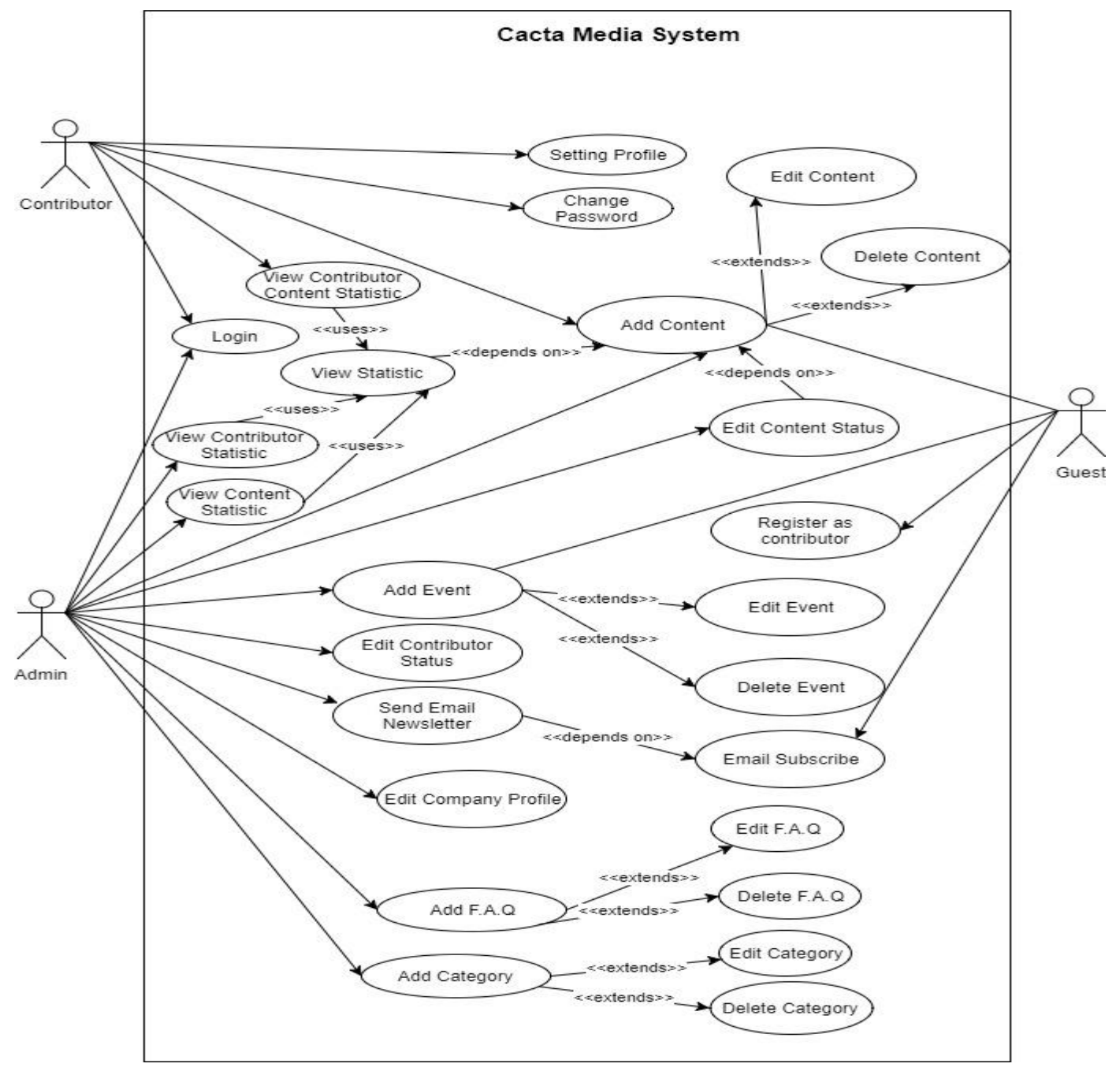

Fig. 3. Use Case Diagram of the Cacta Media System 
In addition to designing the Use Case Diagram, ERD design is also carried out to do the database design. Following is the ERD design on Cacta Media

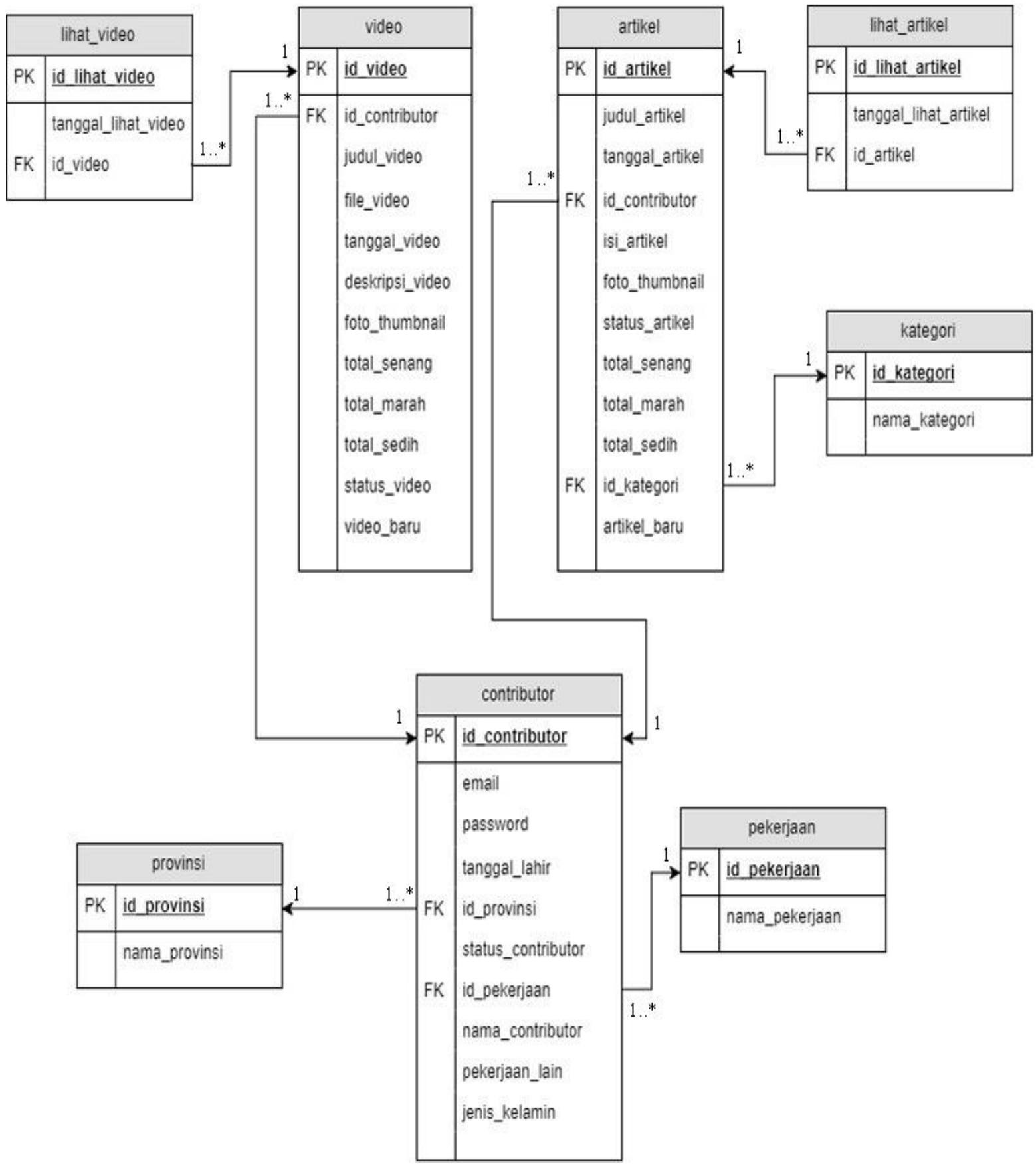

Fig. 4. Entity Relationship Diagram of Cacta Media

\section{Results And Discussion}

From the research conducted, a web-based information and entertainment media portal was produced called Cacta Media. This display page can be accessed at http://media.cactapictures.com/. Following is the display of the main page screenshot from the Cacta Media website. 


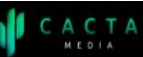

HEADLINE

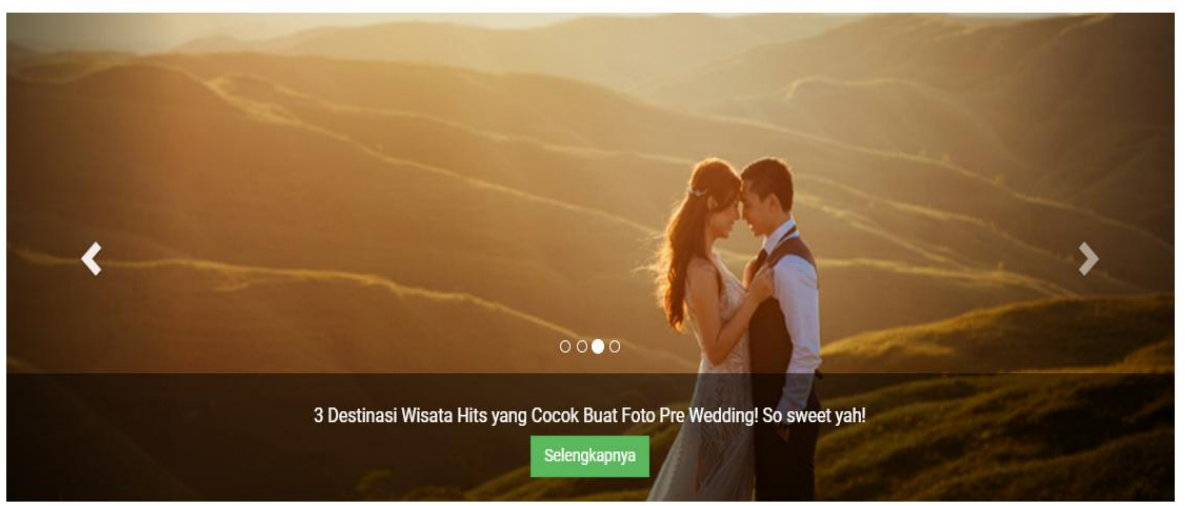

ARTIKEL TERKINI

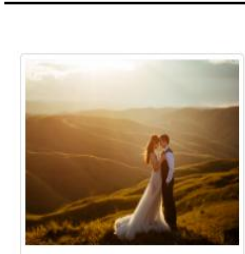

3 Destinasi Wisata Hits yang Cocok Buat Foto Pre Wedding So sweet yah!

CACTA TV

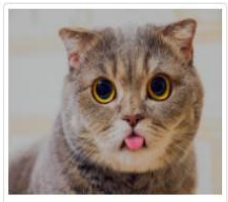

Lihatlah tingkah lucu kucing ini!

\section{KALENDER EVENT}

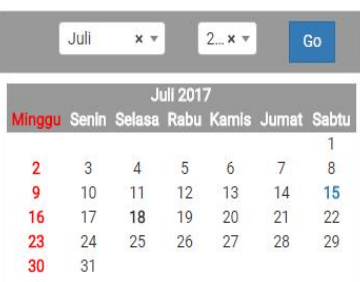
Ini!
Alasan Kenapa Malang Menjadi Venue Folk Music Festival Tahu

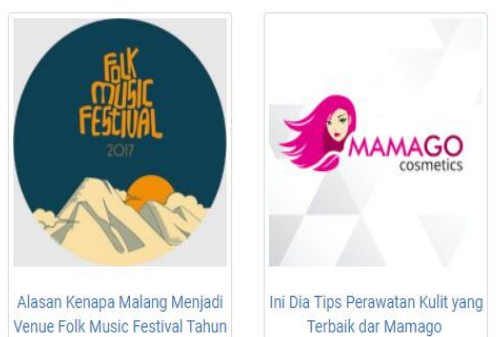

Terbaik dar Mamago

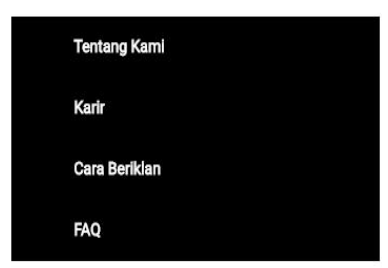

EMAIL SUBSCRIBE

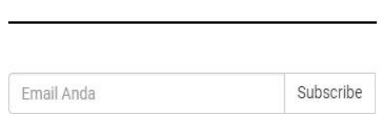

Ingin selalu up to date dengan berita-berita kami? silahkan isi

email anda untuk berlangganan berita kami

Fig. 5. Display of the Cacta Media Main Page

\section{Application Evaluation}

The following is an evaluation of Cacta Media's application of five measurable human factors:

\section{Time to learn}

Learning time needed by users in using the Cacta Media application can be said to be quite fast. This is evidenced from the questions in questionnaires number 1 and 2, both in terms of guest, contributor, or admin. The majority of respondents answered that they already understood the use of the Cacta Media application.

2. Speed of performance 
Based on the results of the evaluation questionnaire $\mathrm{C}$ in questions number 3 and 4 , it shows that the performance of the Cacta Media application is good enough from the guest, contributor, or admin side. The majority of respondents answered that the performance of the Cacta Media website is good.

3. Rate of errors by users

The level of error committed by users in using the Cacta Media application can be said to be quite small. This is evidenced from the questionnaire questions number 5 and 6 , where the questions given to the guest, contributor, and admin show that they have a small error rate.

\section{Retention over time}

Based on questionnaires number 7 and 8 , the data shows that respondents who acted as guest, contributor, and admin feel that it is easy enough to remember the use of this application.

\section{Subjective satisfaction}

The subjective satisfaction of the Cacta Media application for users has been fulfilled, this is evidenced by the results of questionnaires numbers 9 and 10 which indicate that the Cacta Media application has met the expectations of the user.

\section{Conclusions}

Based on the analysis, design, development and evaluation of the Cacta Media web application, it can be concluded that:

1. The features in the Cacta Media web-based portal can be utilized by the public to meet the needs for information and entertainment. The desired content is based on the results of the needs collection questionnaire is also appropriate where there is content in the form of articles and videos.

2. The Cacta Media web-based portal can facilitate if there are visitors who are interested in becoming content contributors at Cacta Media. Where the contributor has a feature to add article or video content to the Cacta Media portal. In terms of business, with the contribution of course Cacta Media will be increasingly rich in content. When the content is more and more varied and will certainly be more interesting for Cacta Media portal website visitors.

3. Facebook Pixel has been successfully implemented in the Cacta Media web-based portal. Where the main purpose of the Facebook Pixel is that Cacta Media can map and record audience activities that come to the Cacta Media web-based portal. So that when audience behavior is possessed, Cacta Media can help companies or brands that want to advertise more efficiently and are targeted to use Facebook advertising. In Facebook advertising, there is a retargeting and lookalike audience feature.

\section{A. Suggestion}

The Cacta Media web-based portal application can still be developed to be even better. The suggestions or input found from the questionnaire and suggestions from the author for the further development of Cacta Media are as follows:

1. Mobile application development can be done. Mobile users, especially in Indonesia, are very high. So that it will be a great opportunity if the Cacta Media application is also developed in the form of mobile apps for both Android and iOS OS users.

2. Improve the display so that the display can be more attractive.

3. Added a feature to login via Facebook for contributors.

4. Add share features for other social media.

5. Strengthen security and code efficiency. In its implementation, a better security system and code efficiency are needed so that the system becomes lighter for anyone to access and does not consume large resources at the hosting service provider.

Added Google Tag Manager feature to track which can help in advertising using Google Adwords.

\section{References}

We Are Social, "Digital in 2017: Southeast Asia Regional Review," We Are Social, 2017. [Online]. Available: https://wearesocial.com/special-reports/digital-southeast-asia-2017. [Accessed: 16-Feb-2017].

Blanco, J. a. (2009). Codeigniter 1.7. Birmingham: Packt Publishing.

Connolly, T., \& Begg, C. (2015). Database Systems: A Practical Approach to Design, Implementation, and Management (6th ed.). London: Pearson. 
Facebook. (2017). Facebook Business. Retrieved from https://www.facebook.com/business/a/facebook-pixel

Hidayat, R. (2010). Cara Praktis Membangun Website Gratis : Pengertian Website. Jakarta: PT Elex Media Komputindo Kompas, Gramedia.

JScripters. (n.d.). Presentation of JQuery. Retrieved from JScripters: http://www.jscripters.com/what-is-jquerypresentation/

Kementrian Komunikasi dan Informatika Republik Indonesia. (2014, February 18). Riset Kominfo dan UNICEF Mengenai Perilaku Anak dan Remaja Dalam Menggunakan Internet. Retrieved from Kementrian Komunikasi dan Informatika Republik Indonesia: https://kominfo.go.id/index.php/content/detail/3834/Siaran+Pers+No.+17-PIH-KOMINFO-2-

2014+tentang+Riset+Kominfo+dan+UNICEF+Mengenai+Perilaku+Anak+dan+Remaja+Dalam+Menggunak an+Internet+/0/siaran_pers. 